\title{
PENGUASAAN KONSEP DAN KEMAMPUAN PEMECAHAN MASALAH FISIKA SISWA MELALUI METODE INTEGRATIVE LEARNING
}

\author{
Anggun Variasi Islami ${ }^{1}$, Lia Yuliati ${ }^{2}$, Siti Zulaikah $^{3}$ \\ STMIK Mataram ${ }^{1}$ \\ Universitas Negeri Malang ${ }^{2}$ \\ Universitas Negeri Malang ${ }^{3}$ \\ Email: Anggun Variasi@yahoo.com
}

\begin{abstract}
Abstrak: Penelitian ini bertujuan untuk mengetahui pengaruh penguasaan konsep dan kemampuan pemecahan masalah fisika antara siswa yang dibelajarkan melalui integrative learning dengan siswa yang dibelajarkan melalui inkuiri terbimbing. Jenis penelitian ini adalah kuasi eksperimen. Sampelnya terdiri dari 68 siswa kelas X SMAN 2 Malang, Jawa Timur. Penelitian dilakukan selama 6 minggu. Kedua kelas diberikan tes berupa soal pilihan ganda untuk penguasaan konsep dan soal essay untuk kemampuan pemecahan masalah. Hasil penelitian menunjukkan bahwa penguasaan konsep dan kemampuan pemecahan masalah fisika siswa yang belajar menggunakan integrative learning lebih tinggi dibandingkan dengan yang belajar dengan inkuiri terbimbing.
\end{abstract}

Kata kunci: integrative learning, kemampuan pemecahan masalah, penguasaan konsep

\section{PENDAHULUAN}

Kurikulum 2013 sedang digalakkan oleh pemerintah. Kurikulum 2013 dikembangkan berdasarkan standar dan teori pendidikan berbasis kompetensi. Kurikulum 2013 dirancang untuk memberikan pengalaman belajar seluas-luasnya bagi siswa. Melalui kurikulum 2013 siswa diharapkan mampu untuk mengembangkan sikap, keterampilan dan pengetahuan. Kurikulum 2013 juga mengarahkan untuk membangun kesadaran dan menumbuhkan kemampuan untuk memecahkan masalah secara kreatif (Kemdikbud, 2013) agar dapat memenuhi target pendidikan abad 21.

Pada abad 21 siswa harus memiliki kemampuan yang tinggi untuk menghadapi berbagai tantangan. Pendidikan abad 21 harus memfasilitasi siswa agar lebih mampu untuk menyelesaikan berbagai permasalahan yang hadir. Target penting dari pendidikan abad 21 membelajarkan individu untuk menghadapi masalah dalam kehidupan sehari-hari dengan mudah (Selcuk, 2008).

Fisika merupakan salah satu mata pelajaran yang dapat membantu siswa dalam menghadapi tantangan abad 21. Fisika memiliki peranan besar dalam menunjang ilmu pengetahuan dan teknologi, sehingga menggugah para pendidik untuk dapat merancang dan melaksanakan pendidikan yang lebih baik dan lebih terarah (Chodijah, 2012). Pengajaran fisika tidak dapat mengabaikan hakikat Fisika sebagai sains. Pembelajaran Fisika memerlukan keterlibatan aktif seluruh siswa dalam menemukan sendiri pengetahuan melalui pengamatan eksperimental dan pengukuran kuantitatif.
Hukum Newton merupakan salah satu materi fisika yang memiliki karakteristik dapat dibelajarkan dengan pengamatan eksperimental. Berdasarkan observasi Hukum Newton merupakan materi yang banyak mengalami miskonsepsi. Haratua (2013) mendapatkan bahwa siswa merasa kesulitan dalam menggunakan konsep, menggunakan prinsip dan dalam menyelesaikan permasalahan yang berkaitan dengan Hukum Newton. Berge (2012) mendeskripsikan bagaimana siswa berjuang keras untuk memahami sendiri konsep dan hukum dalam hukum Newton.

Hukum Newton merupakan materi yang sangat erat kaitannya dengan kehidupan sehari-hari siswa. Banyak hal-hal yang dialami siswa baik disekolah maupun di luar sekolah merupakan aplikasi dari Hukum Newton. Materi hukum Newton akan menjawab pertanyaan mengenai "mekanisme apakah yang mengubah gerak?" dan " mengapa suatu benda dapat bergerak lebih cepat dari benda lainnya" (Serway \& Jewett, 2004). Penguasaan konsep Hukum Newton akan menentukan konsep materi selanjutnya karena materi pada fisika saling berkaitan. Selain itu penguasaan konsep pada materi Hukum Newton akan membantu siswa dalam memecahkan masalah terkait. Suatu konsep fisika jika diajarkan sebagaimana mestinya maka siswa akan mampu untuk memecahkan masalah (Hussain, dkk. 2011).

Kemampuan pemecahan masalah pada materi Hukum Newton pada dasarnya merupakan kebutuhan siswa dalam menghadapi kehidupan nyata. Pentingnya mengajarkan dan mengembangkan kemampuan pemecahan masalah harus dipandang sebagai sesuatu yang urgen dan tidak bisa disepelekan 
lagi. Kemampuan pemecahan masalah tidak cukup dijadikan sebagai tujuan pendidikan semata, tetapi juga sebagai proses fundamental yang memungkinkan siswa untuk mengatasi ketidaktentuan masa mendatang (Silaban, 2011). Oleh karena itu, semua siswa diharuskan untuk belajar bagaimana untuk memecahkan masalah yang kompleks yang berkaitan dengan kehidupan nyata.

Konsep-konsep yang dikuasai seharusnya membentuk siswa untuk mampu mengambil keputusan dalam memilih solusi yang tepat ketika dihadapi dengan masalah. Akan tetapi berdasarkan observasi, siswa disekolah jarang melihat prinsip penting dalam fisika untuk menyelesaikan masalah, siswa lebih memilih menggunakan contoh yang telah ada sebagi acuan. Terutama materi pelajaran yang mengandung manipulasi matematika yang kuat. Siswa akan memilih untuk langsung menghitung menggunakan rumus tanpa mempertimbangkan konsep fisika yang terkait. Ringenberg \& Vanlehn (2008) juga mendapatkan bahwa siswa ketika diberikan tugas untuk memecahkan masalah, tidak melakukan analisis konseptual melainkan cenderung untuk mencocokkan dengan masalah yang dipecahkan sebelumnya atau yang terdapat dibuku teks. Bagaimanapun, untuk bisa memecahkan masalah siswa tidak hanya menggunakan kemampuan matematik tetapi juga memerlukan penguasaan konsep (Berge \& Adawi, 2012).

Untuk dapat memecahkan masalah dalam kehidupan nyata, siswa perlu untuk merefleksikan, menghubungkan pengalaman yang terpisah dan mengintegrasikan penguasaan konsep yang dimiliki dengan identitas siswa sendiri sehingga siswa dapat memecahankan permasalahan real world. Akan tetapi yang menjadi kendala adalah siswa dilapangan tidak secara alami mengintegrasikan pengetahuan yang didapatkan. Oleh karena itu dibutuhkan sebuah pembelajaran yang dapat mengintegrasikan dan mengembangkan penguasaan konsep siswa sehingga kompetensi yang diharapkan tercapai yang sesuai dengan ciri belajar abad 21. Integrative learning dapat membantu siswa untuk mengembangkan kemampuan bidang studi berdasarkan kepentingan dalam memecahkan masalah real world (Becker \& Park. 2011; Huber \& Hucthing. 2005; Humphrey, 2005; Wingert, dkk. 2011; Peet, dkk. 2011).

Integrative learning merupakan pembelajaran yang membantu siswa dalam mengkoneksikan atau mengintegrasikan pengetahuannya dan membuat pelajarannya lebih berarti sehingga dapat meningkatkan pencapaiannya dalam pembelajaran yang sesuai dengan kompetensi yang diharapkan. Seperti yang dikatakan oleh Shi (2006) Integrative learning adalah cara untuk meningkatkan pencapaian siswa secara umum dan khusus yang ditunjukkan siswa dalam mengaplikasikan pengetahuan, keterampilan dan sikap pada seting tertentu dan masalah yang kompleks.
Pengintegrasian baik pengetahuan, keterampilan maupun pengalaman siswa yang terpisah akan mampu menarik minat siswa dalam suatu pembelajaran. Siswa perlu untuk melihat relevansi dari konsep-konsep yang dipelajari secara teoritis dengan aplikasi yang sesuai dengan apa yang dihadapi (Freudenberg, dkk. 2010). Siswa akan merasa pembelajarannya bermakna ketika mengetahui apa yang dipelajari disekolah tidak hanya teori melainkan berhubungan erat juga dengan apa yang dijalani dan hadapi baik dimasa sekarang maupun dimasa mendatang.

Integrative learning digunakan dengan harapan dapat menjadikan siswa memiliki penguasaan konsep yang tinggi. Penguasaan konsep yang tinggi dapat membantu siswa memilih solusi yang tepat dalam memecahkan masalah secara kontekstual sehingga menjadikan siswa mampu beradaptasi dengan dunia kerja abad 21 . Dewasa ini siswa harus fleksibel, integratif dan adaptif terhadap kehidupan sehari-hari (Peet, dkk. 2011). Siswa harus tanggap dengan pengetahuan yang baru, kebiasaan kerja baru yang muncul dan perubahan lingkungan kerja. Siswa yang tanggap dengan pengetahuan, kebiasaan dan perubahan yang baru akan memiliki penguasaan konsep yang tinggi dan berdampak pada kemampuan pemecahan masalah.

\section{Integrative Learning}

Integrative learning adalah perpaduan dan peningkatan pencapaian yang ditunjukkan pada pembelajaran secara umum maupun secara khusus melalui aplikasi pengetahuan, keterampilan, dan tanggung jawab mengenai suatu keadaan yang baru dan permasalahan yang kompleks [11]. Integrative learning merupakan pembelajaran yang membantu siswa dalam berbagai hal seperti (a) Mengintegrasikan pengetahuan dari berbagai rangkaian pembelajaran; (b) Mengaplikasikan pengetahuan yang diperoleh dari satu tempat kesituasi yang baru; (c) Menghubungkan pengalaman belajar ke real world; dan (d) Mengidentifikasi dan menghubungakn antara pengetahuan implisit dan eksplisit [37].

Secara umum integrative learning ini menekankan pada beberapa domain, yaitu:

1. Menjadi siswa yang intensional dan reflektif

Pada domain ini mengacu pada pengembangan kemampuan untuk mengatur dirinya sendiri untuk bertanggung jawab terhadap pembelajarannya, menggambarkan pengalaman dan mengembangkan kemampuan dalam mencari dan mengidentifikasi suatu makna secara terus menerus dari pembelajaran dan pengalaman hidup.

2. Memiliki sebuah proses orientasi terhadap pengetahuan dan pembelajaran

Pada domain ini diasumsikan siswa perlu untuk mengaplikasikan pengetahuan akademik ke permasalahan kehidupan nyata agar mengetahui apa yang diketahui dan bagaimana untuk menggunakan pengetahuan dimasa depan. Melalui 
aplikasi, siswa mampu mengembangkan pengetahuan, keterampilan, dan membiasakan pikiran untuk menunjukkan tantangan yang seringkali ambigu dalam kehidupan. Intinya, pengalaman yang terintegratif akan membantu siswa bagaimana untuk mengidentifikasi, mensintesis dan mengaplikasikan pengetahuan dari berbagai area.

3. Bekerja dengan orang lain untuk membahas isu sosial

Domain ini menyiapkan siswa untuk berkontribusi langsung ke masyarakat luas, belajar untuk berhubungan dengan orang lain untuk memperluas pengetahuan dan dapat bekerja secara efektif di lingkungan yang berbeda. Diskusi kelas dapat membantu siswa untuk meningkatkan kemampuan siswa pada domain ini.

Diskusi kelas sangat penting dalam pembelajaran yang aktif. Diskusi kelas dapat memenuhi tiga tujuan intruksional [3] yaitu:

Pengintegrasian baik pengetahuan, keterampilan maupun pengalaman siswa yang terpisah akan mampu menarik minat siswa dalam suatu pembelajaran. Siswa perlu untuk melihat relevansi dari konsep-konsep yang dipelajari secara teoritis dengan aplikasi yang sesuai dengan apa yang dihadapi [20]. Siswa akan merasa pembelajarannya bermakna ketika mengetahui apa yang dipelajari disekolah tidak hanya
1. Diskusi dapat meningkatkan kemampuan berpikir siswa;

2. Diskusi dapat membantu siswa mengkontruksikan pemahamannya sendiri;

3. Diskusi dapat meningkatkan keterlibatan siswa sehingga pembelajaran menjadi bermakna.

Terdapat enam dimensi dari integrative learning [37], yaitu:

1. Mengidentifikasi, mendemontrasi, dan mengadaptasikan pengetahuan yang diperoleh melalui berbagai konteks

2. Menyesuaikan diri terhadap perbedaan untuk membuat sebuah solusi

3. Memahami dan mengatur diri sendiri sebagai seorang pelajar.

4. Menjadi seorang yang reflektif, bertanggung jawab dan relasional

5. Mengidentifikasi dan melihat perspektif sendiri dan orang lain.

Mengembangkan seorang yang profesional dalam mengidentifikasi secara digital teori melainkan berhubungan erat juga dengan apa yang dijalani dan hadapi baik dimasa sekarang maupun dimasa mendatang.

Integrative learning digunakan dengan harapan dapat menjadikan siswa memiliki penguasaan konsep yang tinggi. Penguasaan konsep yang tinggi dapat membantu siswa memilih solusi

Tabel 1. Tahapan Integrative Learning

\begin{tabular}{|c|c|c|}
\hline No. & Sintaks & Keterangan \\
\hline 1. & Informed Exploration & $\begin{array}{l}\text { mengidentifikasi masalah, survey atau } \\
\text { mengkaji literatur, dan mendefinisikan } \\
\text { masalah }\end{array}$ \\
\hline 2. & Enactment & $\begin{array}{l}\text { mengumpulkan data dan menyelesaikan } \\
\text { masalah melalui praktikum atau diskusi } \\
\text { kelompok }\end{array}$ \\
\hline 3. & $\begin{array}{l}\text { The Evaluation Phase: Local } \\
\text { Impact }\end{array}$ & $\begin{array}{l}\text { Mempresentasikan hasil dari praktikum } \\
\text { atau diskusi }\end{array}$ \\
\hline 4. & $\begin{array}{l}\text { The Evaluation Phase: Broader } \\
\text { Impact }\end{array}$ & $\begin{array}{l}\text { mengaitkan dengan berbagai bidang yang } \\
\text { siswa ketahui yang dapat membantu } \\
\text { pencapaian kompetensi }\end{array}$ \\
\hline
\end{tabular}

(Ritland, 2003)

yang tepat dalam memecahkan masalah secara kontekstual sehingga menjadikan siswa mampu beradaptasi dengan dunia kerja abad 21. Dewasa ini siswa harus fleksibel, integratif dan adaptif terhadap kehidupan sehari-hari [38]. Siswa harus tanggap dengan pengetahuan yang baru, kebiasaan kerja baru yang muncul dan perubahan lingkungan kerja. Siswa yang tanggap dengan pengetahuan, kebiasaan dan perubahan yang baru akan memiliki penguasaan konsep yang tinggi dan berdampak pada kemampuan pemecahan masalah.

\section{Penguasaan Konsep}

Konsep adalah balok-balok bangunan dasar untuk berpikir dan berkomunikasi, terutama untuk pemikiran tingkat tinggi (Arends, 2012). Suatu konsep dapat dibentuk melalui pengalaman langsung dengan objek atau kejadian dalam kehidupan nyata. Penguasaan konsep dapat diartikan sebagai kemampuan seseorang dalam mengungkapkan kembali suatu objek tertentu berdasarkan ciri-ciri yang dimiliki oleh objek tersebut.

Menurut Silaban (2014) Penguasaan konsep adalah usaha yang harus dilakukan oleh siswa dalam $m$ dan mentransfer kembali sejumlah informasi dari suatu materi pelajaran tertentu yang dapat 
dipergunakan dalam memecahkan masalah, menganalisa, menginterpetasikan pada suatu kejadian tertentu. Lebih ringkasnya penguasaan konsep adalah hasil dari kegiatan intelektual.

Belajar konsep melibatkan proses mengonstruksikan pengetahuan dan mengorganisasikan informasi menjadi struktur-struktur yang komprehensif dan kompleks (Arends, 2012). Penguasaanan konsep merupakan bagian dari hasil dalam komponen pembelajaran.konsep, prinsip dan struktur pengetahuan dan pemecahan masalah merupakan hasil belajar yang penting pada ranah kognitif. Penguasaan konsep ditandai dengan keaktifan siswa terhadap aktifitas dan pengembangan ide dalam proses pembelajaran (Madu \& Amaechi, 2012). Penguasaan konsep merupakan bagian dari hasil belajar pada ranah kognitif. Sehingga penguasaan konsep diartikan sebagai kemampuan seseorang dalam mengungkapkan kembali suatu pengetahuan yang diperoleh melalui pengalaman langsung, ditandai dengan keaktifan siswa terhadap aktifitas dan pengembangan ide dalam proses pembelajaran dan memerlukan proses berpikir tingkat tinggi.

\section{Kemampuan Pemecahan Masalah}

Pemecahan masalah menurut Malone (2006) yaitu proses yang menghubungkan pengalaman, pengetahuan, dan intuisi yang ada sebelumnya untuk menentukan solusi dari masalah dimana prosedur yang jelas tidak diketahui. Pemecahan masalah dapat didefinisikan sebagai proses mental yang lebih tinggi. Baik sikap, pengetahuan sebelumnya, dan aturan heuristik atau algoritmik saling bergabung untuk menghasilkan jawaban atau solusi terbaik terhadap suatu masalah.

Ketika dihadapkan pada permasalahan yang belum pernah dihadapinya sebelumnya, maka harus mengambil langkah-langkah tertentu untuk menyelesaikannya. Empat aspek yang harus diperhatikan ketika seseorang dihadapkan dengan pemecahan masalah yaitu; 1) memahami masalah, 2) beragam pendekatan, 3) faktor-faktor yang mempengaruhi pemecahan masalah (Matlin, 2003).

Selama memahami masalah banyak metode alternatif yang bisa diterapkan, misalnya dengan membuat gambar, tabel, diagram atau bagan untuk lebih memahami secara visual dari masalah yang diberikan. Masalah adalah konstruksi dari suatu penyajian internal Greeno menyatakan, bahwa memahami masalah memiliki tiga syarat yaitu: koheren, korenpondensi, dan hubungan dengan latar belakang pengetahuan (Matlin, 2003).

Untuk membuat pendekatan terhadap masalah dapat digunakan beragam strategi, seperti algoritma, heuristik (aturan yang disepakati dalam pemecahan masalah, meliputi pencarian secara efektif, melihat proporsi ruang masalah yang lebih memungkinkan menghasilkan solusi), analogi (Matlin, 2003).

Kemampuan pemecahan masalah tidak cukup dijadikan sebagai tujuan pendidikan semata, tetapi juga sebagai proses fundamental yang memungkinkan siswa untuk mengatasi ketidaktentuan masa mendatang (Silaban, 2011). Ringenberg \& Vanlehn (2008) mendapatkan bahwa siswa merasa kesulitan ketika diberikan tugas untuk memecahkan masalah. Siswa tidak melakukan analisis konseptual melainkan cenderung untuk mencocokkan dengan masalah yang dipecahkan sebelumnya atau yang terdapat dibuku teks

\section{METODE}

Penelitian ini menggunakan kuasi eksperimen dengan pretest posttest control group design. Populasinya seluruh siswa kelas $X$ SMA Negeri 2 Malang tahun pelajaran 2013-2014, yang terdiri dari 6 kelas pararel dengan jumlah 273 siswa. Sampel dua kelas yang terdiri dari 68 siswa diambil dengan teknik purposive sampling, satu kelas sebagai kelas ekperimen (XB) dan satu kelas sebagai kelas kontrol (XA).

Variabel bebasnya ada dua macam yaitu integrative learning (kelas eksperimen) dan inkuiri terbimbing (pembelajaran konvensional pada kelas kontrol). Variabel terikatnya adalah penguasaan konsep dan kemampuan pemecahan masalah fisika. Instrumen perlakuan dalam penelitian ini adalah RPP, Handout, serta LKS. Instrumen pengukuran terdiri dari tes penguasaan konsep dan kemampuan pemecahan masalah. Materi tes adalah Hukum Newton untuk kelas $X$ semester gasal dan berbentuk tes uraian.

Analisis data menggunakan uji prasyarat analisis dan uji hipotesis. Uji normalitas data penguasaan konsep dan kemampuan pemecahan masalah fisika, diuji dengan tes Liliefors. Uji homogenitas varian diuji dengan Uji Bartlett. Analisis uji hipotesis nilai penguasaan konsep dan kemampuan pemecahan masalah siswa menggunakan Multivariate Analysis of Variance (Manova) dengan taraf signifikansi $5 \%$.

\section{HASIL}

Perbandingan nilai penguasaan konsep dan kemampuan pemecahan masalah fisika yang diperoleh dari penelitian dapat dilihat pada Tabel 2 . Secara ringkas perbandingan nilai rerata penguasaan konsep dan kemampuan pemecahan masalah pada masing-masing kelas ditunjukkan pada Gambar 1 dan gambar 2. Hasil uji normalitas penguasaan konsep kelas eksperimen adalah 0,122 $<0,152(\alpha=0,05)$, sedangkan kelas kontrol diperoleh $0,140<0,152(\alpha=0,05)$, serta uj homogenitasnya $0,58<3,84$; sehingga dapat disimpulkan bahwa data diambil dari populasi yang terdistribusi normal dan homogen. Sedangkan hasil uji 
normalitas kemampuan pemecahan masalah kelas eksperimen adalah 0,085 $<0,152(\alpha=0,05)$, sedangkan kelas kontrol diperoleh $0,115<0,152(\alpha=0,05)$. Hasil uji homogenitasnya $0,70<3,84$; sehingga dapat disimpulkan bahwa data diambil dari populasi yang terdistribusi normal dan homogen.
Hasil Uji beda menggunakan Manova menunjukkan 19,098>3,068. Berdasarkan nilai tersebut maka $\mathrm{Ho}$ ditolak dan $\mathrm{H}_{1}$ diterima dan dapat disimpulkan bahwa terdapat perbedaan penguasaan konsep dan kemampuan pemecahan masalah antara siswa yang belajar dengan integrative learning dan siswa yang belajar inkuiri terbimbing

Tabel 2. Perbandingan Nilai Penguasaan Konsep dan Kemampuan Pemecahan Masalah Fisika Siswa

\begin{tabular}{ccccc}
\hline & & & & \\
\cline { 2 - 2 } Nilai & $\begin{array}{c}\text { Kelas } \\
\text { eksperimen }\end{array}$ & Kelas kontrol & $\begin{array}{c}\text { Kelas } \\
\text { eksperimen }\end{array}$ & Kelas kontrol \\
\hline $\mathrm{N}$ & 34 & 34 & 34 & 34 \\
$\bar{X}$ & 84.26 & 72.21 & 81.03 & 70.24 \\
Xmin & 70 & 60 & 68 & 55 \\
Xmax & 100 & 85 & 93 & 85 \\
Sd & 9.14 & 8.00 & 7.69 & 8.87 \\
\hline
\end{tabular}

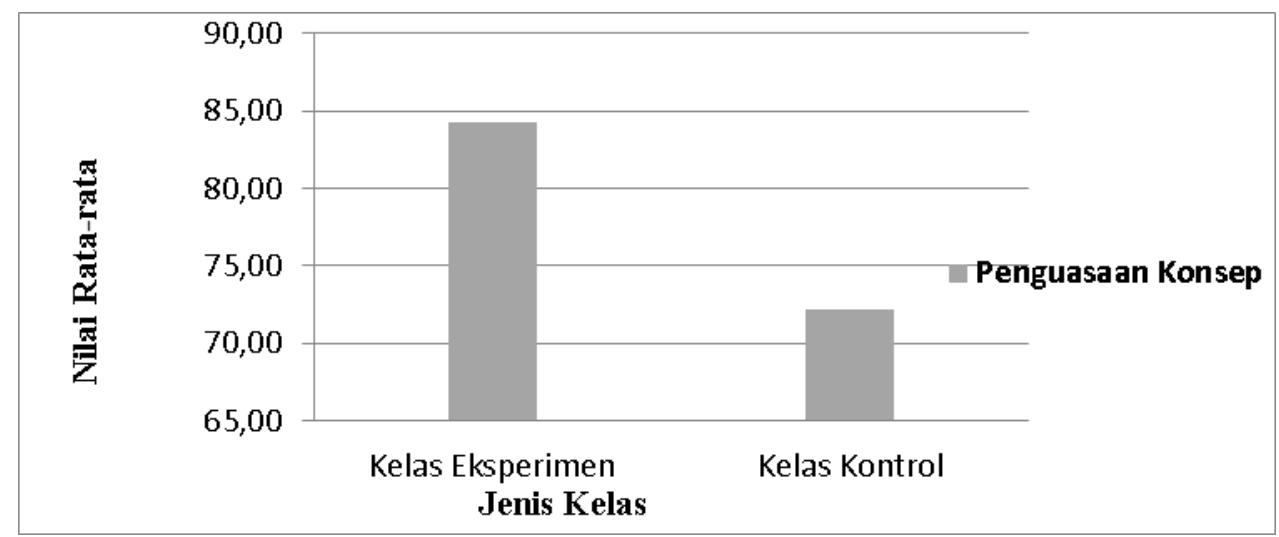

Gambar 1: Diagram Nilai Rata-Rata Penguasaan Konsep

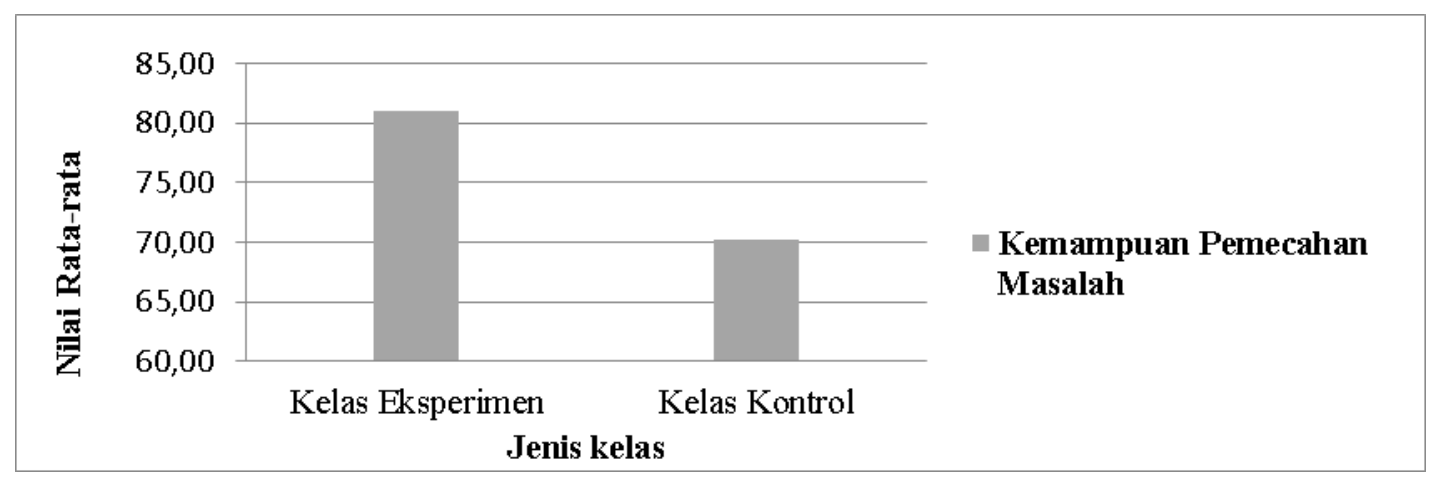




\section{Gambar 2. Diagram Nilai Rata-Rata Kemampuan Pemecahan}

Selanjutnya Uji Tukey telah dilakukan untuk setiap data, baik data penguasaan konsep maupun kemampuan pemecahan masalah. Data penguasaan konsep menghasilkan nilai Qhitung 7,20>2,878 $(\alpha=0,05)$ maka $\mathrm{H}_{0}$ ditolak dan $\mathrm{H}_{1}$ diterima, sedangkan data kemampuan pemecahan masalah menghasilkan nilai Qhitung adalah 7,046>2,878 $(\alpha=0,05)$, maka $\mathrm{H}_{0}$ ditolak dan $\mathrm{H}_{1}$ diterima. Berdasarkan hasil di atas dapat disimpulkan bahwa penguasaan konsep maupun kemampuan pemecahan masalah siswa lebih tinggi belajar dengan integrative learning daripada belajar dengan inkuiri terbimbing.

\section{PEMBAHASAN}

\section{Perbedaan Antara Penguasaan Konsep dan Kemampuan Pemecahan Masalah Siswa Yang Belajar dengan Integrative Learning dan Inkuiri Terbimbing}

Hasil pengujian hipotesis menunjukkan bahwa terdapat perbedaan penguasaan konsep dan kemampuan pemecahan masalah antara siswa yang dibelajarkan dengan menggunakan integrative learning dan inkuiri terbimbing. Nilai rata-rata penguasaan konsep dan kemampuan pemecahan masalah siswa yang belajar dengan integrative learning memiliki perbedaan yang signifikan pada taraf kepercayaan $95 \%$ jika dibandingkan dengan siswa yang belajar dengan inkuiri terbimbing.

Hasil penelitian ini menunjukkan bahwa integrative learning dapat lebih membantu siswa dalam menguasai konsep dan memecahkan masalah. Intergrative learning dapat memperkaya konteks yang dipelajari melalui aktifitas-aktifitas yang dilakukan siswa pada setiap tahapannya. Hal ini didukung oleh hasil penelitian dari Paryanto (2011) yang menyatakan bahwa integrative learning dapat meningkatkan aktifitas dan kemandirian siswa sehingga dapat meningkatkan penguasaan siswa terhadap konsep-konsep terkait. Pengintegrasian yang baik tidak hanya menciptakan hubungan efisien antara informasi baru dan informasi yang telah ada tetapi juga dapat membuat informasi baru lebih konkrit dan lebih mudah untuk dipahami [37]. Integrative learning dilaksanakan sebagai upaya utntuk meningkatkan kemandirian siswa. Integrative learning dan inkuiri terbimbing keduanya dapat memberikan kesempatan kepada siswa untuk aktif dalam membangun pengetahuan sendiri. Pada integrative learning siswa diberikan kebebasan lebih dalam menentukan sendiri jalannya sebuah praktikum sedangkan pada inkuiri terbimbing siswa hanya melakukan sesuai dengan langkah-langkah yang ditetapkan oleh guru. Melalui integrative learning siswa lebih banyak berpikir karena tidak ada urutan yang terstruktur yang diberikan guru sehingga siswa lebih banyak melatih kemampuan menganalisis, mengevaluasi, dan membuat [37].

\section{Pengaruh Integrative Learning dan inkuiri terbimbing terhadap Penguasaan Konsep Siswa} Hasil analisis data menunjukkan bahwa penguasaan konsep siswa yang belajar dengan integrative learning lebih tinggi dibandingkan dengan siswa yang belajar dengan inkuiri terbimbing. Penguasaan konsep yang tinggi disebabkan karena pada tahap informed exploration, guru menyajikan masalah dengan mengintegrasikan masalah konstektual melalui demonstrasi dan tayangan video. Pengamatan yang dilakukan merupakan proses penginderaan yang dapat meningkatkan kemampuan berpikir siswa. Siswa memperoleh pengetahuan fisis tentang suatu obyek dengan mengerjakan atau bertindak terhadap objek itu melalui indera [17]. Informasi-informasi yang diperoleh dari aktivitas pengamatan lantas mendasari kegiatan penalaran logis [42]. Melalui masalah yang disajikan, siswa juga dapat memperoleh informasi-informasi baru mengenai materi yang akan dipelajari. Informasi baru yang didapatkan diharapkan lebih melekat dibenak siswa sehingga siswa mampu mengambil makna dari pengetahuan yang dimilikinya. Berdasarkan hierarki pada pencapaian integrative learning, penyajian masalah konstekstual kepada siswa akan membantu dalam mendapatkan informasi baru yang kemudian akan membentuk pengetahuan baru [12]. Jadi dengan adanya kompleks siswa dapat membentuk pengetahuan baru yang kemudian dapat meningkatkan penguasaan konsep siswa terhadap materi pembelajaran. Selain itu juga beberapa peneliti seperti Hull's dan Sounder (1996); Komalasari (2010); Berns dan Erickson (2001), mengungkapkan bahwa pembelajaran yang menghadirkan masalah kontekstual mendorong siswa untuk membuat hubungan antara pengetahuan yang dimilikinya dengan penerapannya dalam kehidupan sehari-hari. Guru perlu merekonstruksi rancangan pembelajarannya untuk menyediakan masalah dan situasi dunia nyata [29].

Pembelajaran dengan integrative learning juga membuat siswa tidak mudah lupa dengan pengetahuan yang siswa peroleh, karena selain siswa terlibat dalam penemuan konsep pada tahap enactment. Siswa diminta untuk mengkomunikasikan kembali konsep yang didapatkan dalam bentuk esai sehingga dapat lebih melekatkan konsep yang diperoleh. Setiap disiplin ilmu bependapat bahwa tugas menulis dapat membantu siswa menguasai materi, menyusun dan memperjelas 
pemikirannya [16]. Hal tersebut karena pada saat membuat esai siswa kembali melakukan kajian pustaka, dimulai dengan mengumpulkan data baik melalui internet maupun dari buku-buku yang ada di perpustakaan.

Data yang didapatkan kemudian menjadi informasi baru yang akan digunakan sebagai bahan tulisan. Pada saat menulis siswa dapat mengintegrasi dan mensintesis pengetahuan yang siswa dapatkan dalam kelas dengan informasi yang didapatkan selama melakukan kajian pustaka. Dengan demikian, tulisan yang siswa hasilkan akan lebih melekatkan pengetahuan yang dimiliki. Integrative learning mengajarkan siswa untuk mensintesis, menganalisis[37] meng-konseptualisasikan, mendeskripsikan, meng-klasifikasikan, mengukur dan mengobservasi [13]. Jadi pada kelas eksperimen, pembelajaran juga mengoptimalkan pencapaian penguasaan konsep siswa sesuai dengan indikator penguasaan konsep berdasarkan taxonomi Bloom yang direvisi oleh Anderson \& Krawthwohl, 2001. Tulisan siswa juga dapat menjadi pengetahuan baru untuk yang orang lain yang membacanya.

\section{Pengaruh Integrative Learning dan inkuiri terbimbing terhadap Kemampuan Pemecahan Masalah}

Hasil pengujian hipotesis menunjukkan bahwa integrative learning membuat kemampuan pemecahan masalah siswa lebih baik. Kemampuan pemecahan masalah siswa yang belajar dengan integrative learning lebih tinggi dibandingkan dengan siswa yang belajar dengan inkuiri terbimbing. Seorang pembelajar yang integratif dapat memecahkan masalah-masalah yang komplek [5]. Siswa yang dibelajarkan dengan integrative learning dapat dengan mudah mencari solusi terhadap masalah-masalah konstekstual yang diberikan. Belajar dengan integrative learning dapat memicu teraksesnya suatu konsep yang relevan dalam memori untuk memecahkan pertanyaan atau masalah yang dihadapi [10].

Pada tahap awal siswa pada kelas eksperimen diberikan motivasi dengan diberikan kasus-kasus dalam kehidupan sehari-hari yang berkaitan dengan materi pembelajaran yang menarik dan lebih compleks dibandingkan kelas kontrol, sehingga berpengaruh pada tahapan berikutnya dimana siswa akan melakukan pembelajaran dengan lebih antusias. seseorang yang mempunyai motivasi tinggi dalam belajar akan menimbulkan minat yang besar dalam mengerjakan tugas, membangun sikap dan kebiasaan belajar yang sehat melalui penyusunan jadwal belajar dan melaksanakannya dengan tekun [15].

Salah satu faktor yang menyebabkan nilai pemecahan masalah lebih tinggi pada integrative learning karena pada setiap tahapan integrative learning dibelajarkan bagaimana memecahkan masalah. Semakin sering siswa dilatih untuk memecahkan masalah maka kemampuannya akan semakin terasah. Semakin sering siswa dilibatkan analisis masalah maka siswa semakin memahami dalam mencari informasi yang ada dan bagaimana menyelesaikan permasalahan tersebut [18].

Pada tahap informed exploration di integrative learning siswa diajarkan untuk bagaimana mengumpulkan informasi mengenai masalah yang telah diberikan oleh guru. Ketika mengumpulkan informasi siswa dapat menggunakan kemampuan berpikir dasar yang diperlukan untuk melatih siswa menuju proses berpikir kompleks. Siswa dapat menggunakan kemampuan berpikir dasar untuk mengatasi sebuah permasalahan [20].

Kemampuan pemecahan masalah juga dilatihkan pada tahap enactment. Pada tahap enactment siswa memilih data, memetakan data dan menyajikan dalam berbagai tampilan sehingga mudah dipahami. Penyajian data dalam bentuk pemodelan akan membantu siswa untuk lebih memahami permasalahan [7]. Jika permasalahan lebih cepat dipahami maka dapat lebih cepat mengambil keputusan dalam menyelesaikannya [1]. Selain itu siswa juga berdiskusi untuk menganalisis faktor dari setiap masalah untuk mereduksi permasalahan sehingga dapat menentukan faktor yang memperngaruhinya.Pada tahap The Evaluation Phase: Local Impact indikator pemecahan yang dilatihkan adalah membuat sebuah inferensi dimana pada tahap ini setelah siswa mempresentasikan hasil eksperimen atau diskusi, siswa membuat sebuah kesimpulan. Pada tahap akhir yaitu pada The Evaluation Phase: Broader Impact siswa disajikan sebuah kasus baru yang kemudian diminta untuk membuat berbagai solusi untuk masalah tersebut. Pada tahap ini siswa dilatih untuk menjadi lebih kreatif sehingga siswa dapat membuat berbagai alteratif dari berbagai permasalahan.

Pada pembelajaran ini siswa dilatihkan untuk mengintegrasikan pengalaman-pengalaman yang dimiliki dengan konsep-konsep yang diajarkan disekolah untuk mencari solusi-solusi yang tepat memecahkan permasalahan real world. Integrative learning dapat membantu mengaplikasikan pengetahuan akademik untuk menyelesaikan permasalahan real world agar siswa mengetahui apa yang harus diketahui dan bagaimana pengetahuan tersebut berguna untuk kehidupan sehari-hari [40].

\section{Hubungan antara Penguasaan Konsep dan Kemampuan Pemecahan Masalah}

Hasil penelitian menunjukkan bahwa penguasaan konsep siswa memiliki pengaruh yang positif pada kemampuan pemecahan masalah siswa seperti yang telah disimpulkan oleh Silaban (2014) bahwa penguasaan konsep memiliki hubungan yang 
posistif dengan kemampuan pemecahan masalah siswa. Secara tidak langsung hal tersebut juga berhubungan dengan pembelajaran integrative learning. Integrative learning dapat menjadi salah satu cara dalam meningkat kemampuan siswa secara konseptual dan sebagai pendekatan yang kreatif dalam menghadapi berbagai tantangan permasalahan [10].

Dalam menyelesaikan masalah fisika siswa memerlukan proses pemikiran yang khusus dan berbeda-beda antara satu masalah dengan masalah lain. Meningkatkan kemampuan berpikir siswa, guru harus melakukan pembelajaran yang dapat mengembangkan yang dapat meningkatkan penguasaan siswa secara konseptual [13]. Salah satu kemampuan yang dimaksud oleh adalah kemampuan pemecahan masalah. Penguasaan siswa terhadap konsep-konsep fisika akan membantu untuk memilih solusi-solusi yang tepat ketika dihadapkan pada permasalahan.

Penguasaan konsep adalah usaha yang harus dilakukan oleh siswa dalam merekam dan mentransfer kembali sejumlah informasi dari suatu materi pelajaran tertentu khususnya yang dapat dipergunakan dalam memecahkan masalah, menganalisis dan menginterpetasikan pada suatu kejadian tertentu. Lebih ringkasnya penguasaan konsep adalah hasil dari kegiatan intelektual yang sangat diperlukan dalam memecahkan masalah [45].

\section{KESIMPULAN DAN SARAN}

\section{Kesimpulan}

Berdasarkan hasil penelitian dan pembahasan yang diuraikan, dapat ditarik kesimpulan secara umum sebagai berikut.

1. Terdapat perbedaan yang signifikan dari penerapan integrative learning dan inkuiri terbimbing terhadap penguasaan konsep dan kemampuan pemecahan masalah. Hal ini disebabkan karena setiap tahapan integrative learning melibatkan proses berpikir yang berbeda. Melibatkan kemampuan berpikir siswa dalam pembelajaran dapat meningkatkan penguasaan siswa secara konseptual yang berdampak pada kemampuan siswa dalam memecahkan masalah.

2. Siswa yang belajar dengan integrative learning memperoleh penguasaan konsep lebih tinggi daripada siswa yang belajar dengan inkuiri terbimbing. Integrative learning melibatkan siswa dalam proses berpikir lebih banyak sehingga kemampuan intelektual siswa lebih terlatih, akan tetapi kedua kelas sama-sama dapat menyelesaikan soal konsep dan aplikasi dengan baik.

3. Siswa yang belajar dengan integrative learning memperoleh kemampuan pemecahan masalah lebih tinggi daripada siswa yang belajar dengan inkuiri terbimbing. Proses pembelajaran integrative learning lebih banyak melatihkan kemampuan pemecahan masalah daripada inkuiri terbimbing.

\section{Saran}

Berdasarkan hasil penelitian, saran yang dapat diberikan oleh peneliti sebagai berikut.

1. Guru.

a. Guru harus lebih sering melatihkan siswa dalam memecahkan masalah berdasarkan indikator kemampuan pemecahan masalah.

b. Melihat antusiasme siswa pada model pembelajaran yang dilaksanakan terutama pada fase enactment dan the evaluation: broader impact, maka sebaiknya guru sering memberikan pembelajaran yang inovatif terutama pembelajaran menemukan konsep melalui praktikum dan memberikan tugas portofolio yang dapat meningkat penguasaan siswa.

2. Peneliti lain.

a. Pada penelitian ini, masih menggunakan portofolio secara manual. Pada penelitian selanjutnya dapat mengembangkan pembelajaran ini dengan menggunakan ePortofolio.

b. Pada penelitian selanjutnya, peneliti dapat melakukan analisis mengenai materi pembelajaran berdasarkan dimensi-dimensi integrative learning.

\section{DAFTAR RUJUKAN}

Adeyemo, S.A. 2010. Students' Ability Level and their Competence in Problem Solving Task in Physic. Internasional Journal of Education and technology. 1 (2) 35-47

Anderson, L.R. \& Krathwohl, D.R.2001. A taxonomi for Learning, Teaching. And Assessing: A revision of Bloom's Taxonomy of Educational Objective. New York: Longman

Arends, R. I. 2012. Learning to Teach Ninth Edition. United States :McGraw-Hill Companies

Ritland, B. 2003. The role of Desain In research: The Integrative Learning Desain frame work. Educational research Journal 32 (1) 21-24.

Baxter, M. 2001. Making their own way: Narratives for transforming higher education to promote selfdevelopment. Sterling, VA: Stylus.

Becker, K. \& Park, K. 2011. Effects of integrative approaches among science, technology, engineering, and mathematics (STEM) subjects on students' learning: Apreliminary metaanalysis. Journal of STEM Education. 12(5\&6) 23-37.

Berge, M \& Adawi, T. 2012. Comparing Group and Individual problem Solving: A case study from 
Newtonian Mechanics. SEFI. Thessaliniki. Greece.

Berns, R.G. dan Erickson, P.M. 2001. Contextual Teaching and Learning: Preparing Students for the new Economy. The Highlight Zone Research@work, No.5

Bilgin, I. 2009. The effect of guided inguiry instruction incorporating a cooperative learning approach on university students' achievement of acid and bases concepts and attitude toward guided inquiry instruction. Scientific research and Essay. 4 (10). ISSN 1992-2248

Bok, J.B. 2006. Integrative Learning As A Developmental Process: A Grounded Theory Of College Students' Experiences In Integrative Studies. Journal of Counseling and Personnel Services.

Carey, Shelley J. 2006. . Fostering students' abilities to integrate learning. Association of American Collages and Universities. Spring 2011 vol 11(2) 30-31 ISBN 0-11696-98-9

Cheng, Y.C. 2007. Multiple Models of integrated Learning: conception, effectiveness, \& creativity. Asia-Pacific Educational Research Association.

Chodijah, S. Fauzi, A \& Wulan R. 2012. Development of Physics Learning Devices using the Guided Inquiry Model Equipped with Portfolio Assessment on Circular Motion Material. Research Journal of Physics Learning. 1(12) 119 ISSN: 2252-3014

Costa A.L.1985.Develoving of mind. A resourse Book for Teaching Thingking. Virginia: ASCD Publication

Darsono, Max. 2000. Belajar dan Pembelajaran. Semarang: IKIP Semarang Press

Davis, Barbara G. 2013. Tool For teaching edisi 2. Terjemah Elok Dianike. Rajawali Pers: Jakarta.

Ellianati, S.B. 2010. Application of practical models of Problem solving laboratory In an effort to improve the quality of the implementation of basic physics Practicum. Indonesian Education Journal.. 6 (2010) 90-97 ISSN: 1693-1246

Etkina, E. 2006. Scientific Abilities and Their Assessment. Physics Education Research, (Online), 2(15):020103-1-15,

Freudenberg, B. Brimble, M. Vyvyan, M. 2010. The Penny Drops: Can Work Integrated Learning Improve Students' Learning?.e-Journal of Business Education \& Scholarship of Teaching. 4 (1) $42-61$

Gok, T \& Silay I. 2010. The Effects of Problem Solving Strategies on Students' Achievement, Attitude and Motivation. Latin American Journal Physics Education. 4(1): 7-21
Haratua, T \& Silitonga, M. 2013. Remediation of Student Errors Through Problem Solving in Class IX Junior High School. Untan Journal. Vol 2 (12)

Holomoun, M. 2012. Conception Analysis of Physics Subject Teachers Madrasah Aliyah Against the Concept of Style in Silent and Moving Objects. Medan Ministry of Religion. http://sumut.kemenag.go.id accessed May 20, 2013. Houston, K. 2005. How To Think Like A Mathematician.Leeds:Univercity of Leeds.

Huber, Marry T. \& Hutchings, P. 2005. Integrative learning: Mapping The Terain. Association of American Collages and Universities. Summer/Fall 2005 vol 7(4) 4-7 ISBN 0-1169698-9

Hull's, D. \& Souders, Jr.J.C. 1996. The Coming Challenge: Are Community Colleges Ready for the New Wave of Contextual Learners?" Community College Journal, 67(2):15-17

Humphrey, D. 2005. Why Integrative Learning? Why Now? Association of American Collages and Universities. Summer/Fall 2005 vol 7(4) 30-31 ISBN 0-11696-98-9

Hussain, A. Azeem, M. Shakoor, A. 2011. Physics Teaching methods: Scientific Inquiry Vs traditional lecture. Internasional Journal of Humanities and Social Science. 1(19) 269-279

Jonassen, David H. 2004. Learning To Solve Problem Solving. San Fransisco: Pfeifer.

Kayu, D.F. 2003. Problem Based Learning. BMJ, 326

Kemdikbud. Draft 2013 curriculum for socialization. (Online) http://kurikulum2013.kemdikbud.go.id accessed 10 March 2013

Komalasari, K. 2010. Learning Contextual Concepts and Applications. Bandung: Refika Aditama

Madu, B.C \& Amaechi, C.C. 2012. Effect of five-Step Learning Cycle Model on students' Understanding of Concept Relate to Elasticity. Journal of Education and Practice 3 (9) 36-45

Malone, K.L.2006. A Convergence of Knowledge Organization, Problem-Solving Behavior, and Metakognition Research with the Modeling Method of Physics Instruction-Part I. Journal of Physics Teacher Education, 4(1): 14-24.

Matlin, M. W. and Geneseo, S. 2003. Cognition (5th Ed). New Jersey: John Wiley \& Sons Inc.

Mauke, M. I Wayan, S. I Wayan, S.2013. Pengaruh Model Contextual Teaching and Learning Terhadap Pemahaman Konsep dan Kemampuan Pemecahan Masalah dalam Pembelajaran IPA-Fisika di MTs Negeri Negara. e-Journal Program Pascasarjana Universitas Pendidikan Ganesha Program Studi IPA. Volume 3

Paryanto. 2012. Efforts to Improve the Quality of Machining Practice Learning of UNY D3 Mechanical Engineering Students with 
Integrative Learning Models. Education Journal, 2 (3) : 85-90.

Peet, M. Lonn, S. Gurin, P. Boyer, K, Matney M. Marra, Tiffany. Taylor, S \& Daley, Andrea. 2011. Fosrtering Integrative Knowlegge through ePortofolio. Internasional Journal of ePortofolio. 1 (1) $11-31$

Rencher, A. C. 2002. Methods of Multivariate Analysis Second Edition. United State of America: Wiley Interscience

Ringenberg, Michael A. \& Vanlehn K. 2008. Does Solving III-Defined Physics Problem Elicit More Learning Than Conventional problem Solving?. Learning Research and development center. 412-624-3353

Schunk, D, H. 2012. Learning Theories an Educational Perspective, Sixth Edition. Greensboro: Pearson Education

Serway, R. A. \& Jewett, J. W. 2004. Physics for Scientists and Engineers, Sixth Edition. Pomona: Thomson Brooks/Cole

Shi, David E. 2006. Technology and Integrative Learning:Enebling serendipitous Conectivelt across Courses. PEER REVIEW: American Association of collages \& Universitas (AAC\&U). 9(1) 4-7

Silaban, Bajongga. 2014. The Relationship Between Mastery of the Concept of Physics and Creativity with the Ability to Solve Problems in Static Electricity's Main Material. Research Journal for Education. Volume 20 (1): 65 - 75. ISSN 0852-0151

Subiantoro, AW. 2012. The Importance of Practicum in Science Learning. (online) from: http://www.staff.uny.ac.id

Wingert, Jason R. Wasileski, Sally A, Peterson, K. Mathews, L.G. Lanau A.J. Clarke David. 2011. Enhencing Integrative Learning Experiences: Evidence of student Perpectiona of Learning Gains from Cross-course Interaction. Journal of scholarship of teaching and Learning. 11 (3): 34-57. 